\title{
The role of vitamin $C$ in alteration of enzymes responsible of energy metabolism induced by administration of tamoxifen to mouse*
}

\author{
Zaina Zuhair, Hasan ALamri
}

Girls College of Education, King Abdulazia University, Jeddah, Saudi Arabia.

Email: Sala201018@gmail.com

Received 29 April 2011; revised 2 June 2011; accepted 13 June 2011.

\begin{abstract}
Tamoxifen is a synthetic non-steroidal ant estrogen. It was suggested to study the role of vitamin $C$ in alteration of enzymes responsible of energy metabolism induced by administration of tamoxifen to mouse. The effect of tamoxifen and tamoxifen with vitamin $C$ on some activity of enzymes in the mice representing glycolytic, gluconeogenic and glycogenolytic pathway and also, liver function enzymes represented by aspartate aminotransferase (AST), alanine amino-transferase (ALT), acid phosphatase (ACP) and alkaline phosphatase (ALP) were studied. The present results showed that a significant $(p<0.001)$ increase in glycolytic enzymes (HK, PK, GPI and PFK), gluconeogenic enzymes, G-6-Pase, acid phosphatase (ACP), alkaline phosphatase (ALP) and glucose, were observed in treated groups, while LDH, glycogen phosphorylase, AST and ALT enzymes activities showed significant $(p<0.01)$ reduction. The present results also, showed that significant reduction in glycogen, total protein, total cholesterol, uric acid, urea, and creatinine in treated mice as compared to the normal healthy control group. However, normal control mice treated with tamoxifen and vitamin $C$ showed no side effects of most parameters compared to the normal healthy control group. It was concluded that vitamin C may prevent tamoxifen-induced testes toxicity in mice.
\end{abstract}

Keywords: Adult Male Albino Mice; Tamoxifen Vitamin C; Liver Tissue Homogenates

\section{INTRODUCTION}

Tamoxifen is one of the most effective synthetic nonsteroidal ant estrogenic compounds, it is widely used in the treatment of advanced hormone-dependent breast cancer which is the most worldwide common form of cancer in women [1] by binding to estrogen receptors and suppressing epithelial proliferation [2,3] and as adjuvant therapy following surgery in early stages of the disease. Tamoxifen is also, proposed for the prevention of cancer amongst high risk women [4]. Such an approach requires objective and accurate evolution of the side effects which could result from the administration of this drug.

Some studies showed that tamoxifen has adverse side effects on the cardiovascular system, bone metabolism and liver. Also, tamoxifen caused cytotoxicity on primary cells from human multiple organs: Kidney, liver and lung [5].

Vitamin $C$ is an antioxidant agent that limits the injury produced by drugs. Vitamin $\mathrm{C}$ is an essential nutrient that functions as a non-enzymatic antioxidant in the cytosol. The various experimental studies indicated that this vitamin is effective in preventing the oxidative renal damage and stress [6].

It is well known that the liver is one of the major target organs affected by drug, where the most metabolic processes are usually located. The most important metabolic pathways are glycolysis, gluconeogenesis and glycogenolysis contributions of these pathways elucidate the metabolic relationship between glucose, glycogen and energy release. The characteristic pattern of change in some enzymes activity representing glycolytic pathways as (hexokinase (HK), pyruvate kinase (PK), phosphofructokinase (PFK), lactate dehydrogenase (LDH), and glucose phosphate isomerase (GPI); glycogenolytic pathways as glycogen phosphorlase, glucose-6-phosphatase (G-6-Pase); gluconeogenic pathways as fructose-1-6 diphosphatase (F-D-P ase), phosphoenolpyruvate carboxykinase (PEPCK). as well as glycogen content in soft tissue and glucose in serum as bioenergetics parameters of critical importance in reflecting the physiological alteration of animals under the stress [7].

Carbohydrates and amino acids are one of the important parameters which could be used as another indicator 
of the stress by molluscicides [8].

The aim of the present work is to cast more light on the toxic effect of tamoxifen on some liver enzymes in mice representing metabolic pathways are glycolysis, gluconeogenesis and glycogenolysis and the role of vitamin $\mathrm{C}$ in minimizing the toxicity induced by tamoxifen.

\section{MATERIALS AND METHODS}

\subsection{Experimental Animals}

Adult male albino mice in the present investigation were obtained from Schistosome Biological Supply Program (SBSP), Theodor Bilharz Research Institute, Cairo, Egypt. They were 3 months old and of an average weigh of 25 $30 \mathrm{~g}$. They were fed ad labium with a standard diet. They were kept in cages and acclimatized in the laboratory for 7 days prior to experimentation.

\subsection{Applied Drugs}

Tamoxifen and vitamin $\mathrm{C}$ were purchased from Chemical Industries Development (CID) Company, Al-Harm, Giza, Egypt as tablets for oral administration, each tablet contains $40 \mathrm{mg}$ and $500 \mathrm{mg}$ of the active ingradients, respectively. The therapeutic dose of each drug for mice was calculated according to the table given by Paget and Barnes [9].The therapeutic doses of tamoxifen and vitamin $C$ were calculated as $0.1 \mathrm{mg} / \mathrm{kg}$ and $1.25 \mathrm{mg} / \mathrm{kg}$ for mice, respectively. The doses were given orally and estimated according to the body weight of the mouse.

\subsection{Experimental Design}

The mice were divided into three equal groups. The 1st group served as control and received distilled water. The 2nd group was daily administrated $0.1 \mathrm{mg}$ tamoxifen. the 3th group were given daily $1.25 \mathrm{mg}$ vitamin $\mathrm{C}$ simultaneously with the dose of $0.1 \mathrm{mg}$ tamoxifen. All the doses were given daily for 28 days and sacrificed after month. Animals'sacrifice and examination stared 4 weeks post treatment; it was done on successive days. In each day only two animals from each group were sacrificed. Each liver was then taken and divided into $0.25 \mathrm{~g}$ portions. The liver portion were taken and covered with aluminum foil and stored at $-4^{\circ} \mathrm{C}$ until used for homogenization and biochemical assays. All mouse were subjected to determine HK, PK, GPI, LDH, PFK, FD Pase, PEPCK, G-6-Pase, AST, ALT, ADP, ALP and glycogen phosphorylase enzyme activities as well as, glycogen and protein content in liver tissue. Glucose, total cholesterol uric acid, urea, and creatinine in sera.

\subsection{Preparation of Liver Tissue Homogenates}

On the day of each the following enzyme parameter assay, one portion weighing $0.25 \mathrm{~g}$ from each liver aluminium package was taken and homogenized in $2.5 \mathrm{ml}$ of the specific recorded solution to give $10 \%$ concentration and then used for assay. Similar periods elapsed between homogenization and enzyme was assayed in two livers from each group on the same days.

\subsection{Bleeding and Preparation of Serum}

Blood samples were collected, after 4 weeks post-treatment. Collected blood samples were centrifuged at 3000 rpm for 10 minutes and sera were stored immediately at $-80^{\circ} \mathrm{C}$ until time of analysis.

\subsection{Enzyme Assays}

All physiological parameters determined in this study were determined spectrophotometrically, using reagent kits purchased from BioMerieux Company, France.

Hexokinase (HK) was assayed according to the method of Uyeda and Raker [10]. Pyruvatekinase (PK) according to the method of McManus and James [11]. Glucose phosphate isomerase (GPI) according to the method of King [12], Phosphofructokinase (PFK) according to the method of Zammit et al. [13] and Lactate dehydrogenase (LDH) activity according to the method of Cabaud and Wroblewski [14]. Phosphoenolpyruvate carboxykinase (PEPCK) according to the method of Suarez et al. [15] and Glucose-6-phos-phatase according to the method of Swanson [16]. Fructose-1, 6-diphosphatase (FD Pase) according to the method of Sand et al. [17] and Glycogen phosphorylase according to Hedrick and Fischer [18]. Aspartate and alanine aminotransferases according to the method of Reitman and Frankel [19]. Acid phosphatase and alkaline phosphatase activities according to Fishman and Ferner [20] and King and King [21] respectively. Total protein according to the method of Lowry et al. [22]. Glycogen according to the method of Nicholas et al. [23]. Glucose according to the method of Trinder [24].

Sera were used for measuring concentrations of glucose, total cholesterol, uric acid, urea and creatinine.

\subsection{Statistical Analysis}

Data were analyzed by comparing values for different treatment groups with the values for individual controls. Results are expressed as mean \pm S.D. The significant differences among values were analyzed using analysis by student's t-test for comparing the means of experimental and control groups [25].

\section{RESULTS}

The present results in the Table 1 and Figure 1 showed that very highly significant $(p<0.01)$ reduction in Lactate $(\mathrm{LDH})$ enzyme activity in mice treated with Ta- 
moxifen $(32.5 \pm 2.3)$ as compared to the normal control $(42.32 \pm 2.6)$, while significant $(p<0.001)$ increase was noticed in other glycolytic enzymes hexokinase (HK), pyruvatekinase (PK), phosphofructokinase (PFK) and glucose phosphate isomerase (GPI) as compared to the normal healthy control. The enzymes activities in treated mice were $0.141 \pm 0.13,7.8 \pm 2.1,26.2 \pm 2.2$ and $1201 \pm$ $2.1)$ and in control mice were $(0.085 \pm 0.05,5.8 \pm 2.1$, $18.21 \pm 1.4$ and $88.6 \pm 8.2) \mu \mathrm{mol} / \mathrm{min} / \mathrm{mg}$ protein, respectively. Moreover, treatment of mice with the tamoxifen and vitamin $\mathrm{C}$ recorded no significant difference in all glycolytic enzymes as compared to control group. A noticeable remark on the effect of tamoxifen with vitamin $\mathrm{C}$ pointed out to that there is no side effects on all glycolytic enzymes (LDH, HK, PK \& GPI) as compared to the normal healthy control group.

The present results (Table 2 and Figure 2) showed that the effect of tamoxifen on some gluconeogenic enzymes. Significant increase $(p<0.001)$ in the levels of FDPase and PEPCK was noticed in treated group as compared to the normal group. The percentage of increases were $39.66 \%$ and $48.57 \%$, respectively Figure 1, Table 2 showed a very highly significant increase $(p<$ $0.001)$ in G-6-Pase, while a highly significant reduction $(p<0.001)$ in glycogen phosphorylase was noticed in treated group as compared to the normal healthy control group. The percentage of increases was $35.15 \%$ and $51.54 \%$ respectively.

Moreover, treatment of mice with the tamoxifen and vitamin $\mathrm{C}$ recorded no significant difference in all glycolytic, gluconeogenic and glycogenolytic enzymes as compared to control group. A noticeable remark on the effect of tamoxifen with vitamin $\mathrm{C}$ pointed out to that there is no side effects on all glycolytic, gluconeogenic and Glycogenolytic enzymes as compared to the normal healthy control group.

Table 3 and Figure 3 showed that highly significant reductions $(p<0.01)$ in aspartate aminotransferase (AST) and alanine aminotransferase (ALT) enzymes in mice treated with tamoxifen while significant $(p<0.01)$ increases were observed in acid phosphatase (ACP) and alkaline phosphatase (ALP) levels as compared to the normal healthy control group.

Moreover, treatment of mice with the tamoxifen and vitamin $C$ indicated that no significant difference in the level of liver function enzymes as compared to control group. Treatment of the normal healthy mice with the tamoxifen and vitamin $\mathrm{C}$ showed no side effects on the level of liver function enzymes.

Table $\mathbf{4}$ and Figure $\mathbf{4}$ showed that highly significant reductions $(p<0.01)$ in glycogen and total protein levels in treated mice with tamoxifen as compared to the normal healthy control group. The percentages of reductions were $31.01 \%$ and $37.56 \%$ respectively. The table shows a highly significant increase $(p<0.01)$ in glucose level (28.1\%). The present results in the Table 4 showed that very highly significant $(p<0.01)$ reduction in total cholesterol, uric acid, urea and creatinine in mice treated with tamoxifen as compared to the normal healthy control. The percentages of reductions were $25.71 \%, 34.2 \%$, $27.42 \%$ and $19.32 \%$, respectively. Moreover, treatment of mice with the tamoxifen and vitamin $\mathrm{C}$ recorded no significant difference in the level of glucose, total cholesterol, uric acid, urea and creatinine as compared to control group. Treatment of the normal healthy mice with the tamoxifen and vitamin $\mathrm{C}$ showed no side effects on the level of glucose, total cholesterol, uric acid, urea and creatinine.

\section{DISCUSSION}

In the present study, significant increase in glycolytic enzymes HK, PK, GPI and PFK were observed in treated group with tamoxifen, while LDH enzyme activity showed significant reduction. The enhancement in the activities of glycolytic enzymes in treated mice could be attributed to increase metabolic activities of treated liver tissues to compensate the inhibition of host Krebs' cycle of host caused by treatment with tamoxifen [26,27]. LDH inhibition revealed the aerobic-anaerobic switch induced by treatment with tamoxifen [27]. Kuser et al. [28] indicated that lactate is accumulated and glycogen depleted confirming inhibition of aerobic respiration and stimulation of anaerobic glycolysis through hexokinase, a rate limiting enzymes of glycolysis. Some authors reported that tissue damage followed the release of cellular enzymes such as LDH [29,30]. Besides in spite of the decrease in LDH activity, there was insignificant change in D-lactate and pyruvate level as compared to untreated snails, as reported by Reddy et al. [31].

Concerning gluconeogenic enzymes activities (Fructose-1,6-diphosphatase and Phosphoenolpyruvate Carboxykinase), the present results showed significant elevations in treated mice, where the significant increase in gluconeogenic enzymes fructose-1,6-diphosphatase is due to depletion of glucose in the treated mice, where the ratio of glycogen to glucose levels in liver is known to be regulated by the balance between glycogen synthesis and degradation capacities. The increase influx of glucose into glycolytic flux and enhanced glycogen stored lead to stimulation of the enzymes [32]. The nature of the end product formed is dependent on the competition for PEP by the two enzymes pyruvate kinase (PK) and phosphoenolpyruvate carboxykinase (PEPCK). Stimulation of PK in treated animals ascertained the stimulation of the gycolytic flux previously reported by Horemans et al. [33] and Ahmed and Gad [26]. With respect to G-6- 
Table 1. Effect of tamoxifen and vitamin $\mathrm{C}$ on some glycolytic enzyme, in mice liver.

\begin{tabular}{|c|c|c|c|c|c|c|c|c|c|c|}
\hline & \multicolumn{10}{|c|}{ Glycolytic enzymes } \\
\hline & \multicolumn{2}{|l|}{$\mathrm{HK}$} & \multicolumn{2}{|c|}{ PK } & \multicolumn{2}{|l|}{ PFK } & \multicolumn{2}{|c|}{ LDH } & \multicolumn{2}{|l|}{ GPI } \\
\hline & Mean $\pm \mathrm{SD}$ & $\begin{array}{c}\% \\
\text { change }\end{array}$ & Mean \pm SD & $\begin{array}{c}\% \\
\text { Change }\end{array}$ & Mean \pm SD & $\begin{array}{c}\% \\
\text { change }\end{array}$ & Mean \pm SD & $\begin{array}{c}\% \\
\text { Change }\end{array}$ & Mean \pm SD & $\begin{array}{c}\% \\
\text { Change }\end{array}$ \\
\hline Contol & $0.085 \pm 0.05$ & & $5.8 \pm 2.1$ & & $18.21 \pm 1.4$ & & $42.32 \pm 2.6$ & & $88.6 \pm 8.2$ & \\
\hline $\begin{array}{l}\text { Mice treated } \\
\text { wth } \\
\text { tamoxifen }\end{array}$ & $0.141 \pm 0.13^{* * *}$ & $64.7 \%$ & $7.8 \pm 2.1 * * *$ & $34.48 \%$ & $26.2 \pm 2.2 * * *$ & $43.88 \%$ & $32.5 \pm 2.3 * *$ & $23.2 \%$ & $1201 \pm 2.1 * * *$ & $35.44 \%$ \\
\hline $\begin{array}{l}\text { mice treated } \\
\text { with } \\
\text { tamoxifen \& } \\
\text { vitamin C }\end{array}$ & $0.082 \pm 0.072$ & $3.53 \%$ & $5.6 \pm 1.5$ & $3.4 \%$ & $18.8 \pm 2.1$ & $3.24 \%$ & $40.12 \pm 3.4$ & $5.2 \%$ & $90.2 \pm 5.3$ & $1.81 \%$ \\
\hline
\end{tabular}

Data are means \pm S.D. of five mice in each test; All values are expressed as $\mu \mathrm{mol} / \mathrm{min} / \mathrm{mg}$ protein; $* * p<0.01 \& * * * p<0.001$

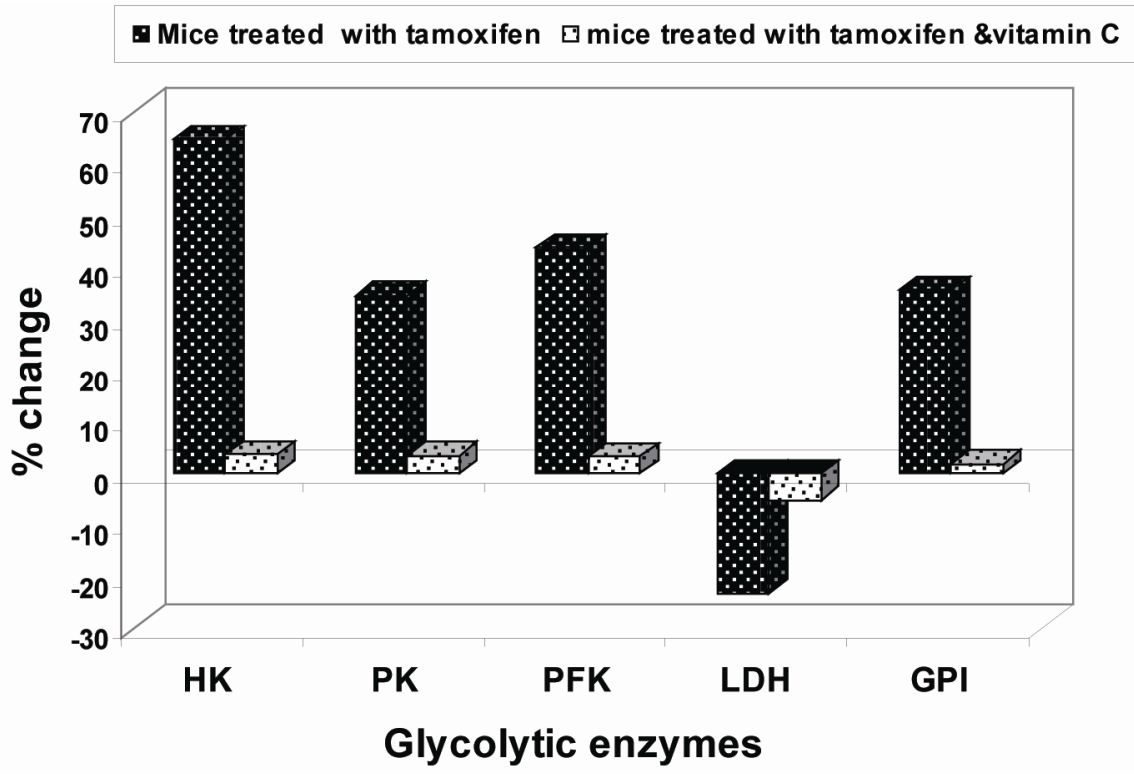

Figure 1. Percentage change in the activity of glycolytic enzyme of mice treated with Tamoxifen and Tamoxifen with vitamin $C$.

Table 2. Effect of tamoxifen and vitamin $\mathrm{C}$ on some gluconeogenic and glycogenolytic enzyme, in mice liver.

\begin{tabular}{|c|c|c|c|c|c|c|c|c|}
\hline & \multicolumn{4}{|c|}{$\begin{array}{l}\text { Gluconeogenic } \\
\text { enzymes }\end{array}$} & \multicolumn{4}{|c|}{$\begin{array}{l}\text { Glycogenolytic } \\
\text { enzymes }\end{array}$} \\
\hline & \multicolumn{2}{|c|}{ FD Pase } & \multicolumn{2}{|c|}{ PEPCK } & \multicolumn{2}{|c|}{ G-6-Pase } & \multicolumn{2}{|c|}{$\begin{array}{l}\text { Glycogen } \\
\text { phosphorylase }\end{array}$} \\
\hline & \multicolumn{2}{|c|}{ Mean \pm SD } & \multicolumn{2}{|c|}{$\%$ change } & \multicolumn{2}{|c|}{ Mean \pm SD } & \multicolumn{2}{|c|}{$\%$ Change } \\
\hline Contol & $11.6 .1 \pm 0.21$ & & $3.5 \pm 1.8$ & & 18.212 .1 & & $1.3 \pm 0.3$ & \\
\hline $\begin{array}{l}\text { mice Treated with } \\
\text { tamoxifen }\end{array}$ & $16.2 \pm 1.8 * * *$ & $39.66 \%$ & $5.2 \pm 0.22 * * *$ & $48.57 \%$ & $24.6 \pm 3.1 * * *$ & $35.15 \%$ & $0.63 \pm 0.32 * * *$ & $51.54 \%$ \\
\hline $\begin{array}{l}\text { mice Treated with } \\
\text { tamoxifen \& vitamin C }\end{array}$ & $12.1 \pm 2.2$ & $4.31 \%$ & $3.6 \pm 0.62$ & $2.86 \%$ & $18.621 \pm 0.72$ & $2.31 \%$ & $1.26 \pm 2.1$ & $3.08 \%$ \\
\hline
\end{tabular}

Data are means \pm S.D. of five mice in each test; All values are expressed as $\mu \mathrm{mol} / \mathrm{min} / \mathrm{mg}$ protein; $* * p<0.01 \& * * * p<0.001$. 


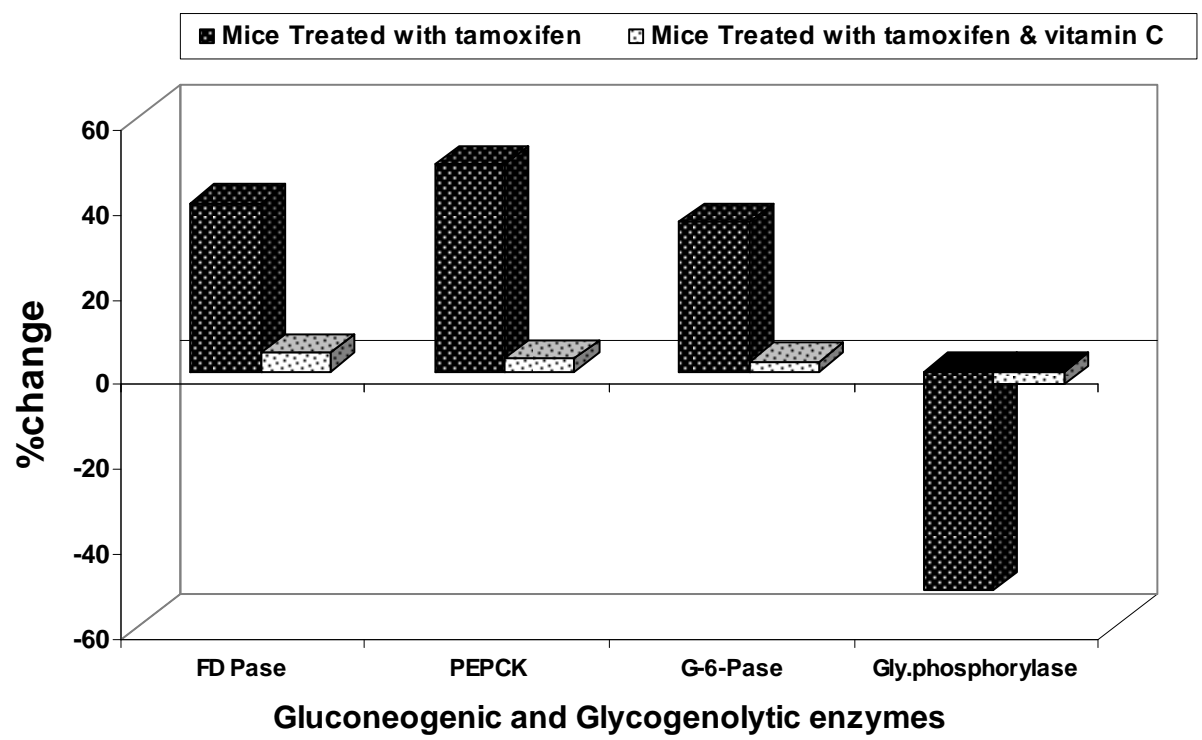

Figure 2. Percentage change in the activity gluconeogenic and glycogenolytic enzyme of mice treated with Tamoxifen and Tamoxifen with vitamin C.

Table 3. Effect of tamoxifen and vitamin $\mathrm{C}$ on liver function enzymes in mice.

\begin{tabular}{|c|c|c|c|c|c|c|c|c|}
\hline \multirow{3}{*}{$\begin{array}{l}\text { Parameters } \\
\text { Treatment }\end{array}$} & \multicolumn{8}{|c|}{ Enzyme activity $\mu \mathrm{mol} / \mathrm{min} / \mathrm{mg}$ protein } \\
\hline & \multirow{2}{*}{$\begin{array}{l}\begin{array}{l}\text { Aspartate aminc } \\
(\mathrm{AST}))\end{array} \\
\text { Mean } \pm \mathrm{SD}\end{array}$} & transferase & \multirow{2}{*}{$\begin{array}{l}\begin{array}{l}\text { Alanine amino } \\
(\mathrm{ALT})\end{array} \\
\text { Mean } \pm \mathrm{SD}\end{array}$} & \multirow{2}{*}{$\begin{array}{l}\text { transferase } \\
\text { \% Change }\end{array}$} & \multicolumn{2}{|c|}{ Acid phosphatase (ADP) } & \multicolumn{2}{|c|}{ Alkaline phosphatase (ALKP) } \\
\hline & & $\%$ change & & & Mean $\pm \mathrm{SD}$ & $\%$ change & Mean $\pm \mathrm{SD}$ & $\%$ change \\
\hline Control & $31.6 \pm 3.1$ & & $21.8 \pm 2.11$ & & $5.8 \pm 1.1$ & & $3.5 \pm 0.52$ & \\
\hline $\begin{array}{l}\text { Mice treated with } \\
\text { tamoxifen }\end{array}$ & $20.5 \pm 1.03 * *$ & $-35.13 \%$ & $12.8 \pm 0.75^{* * *}$ & $-41.28 \%$ & $8.6 \pm 0.31 * * *$ & $48.28 \%$ & $5.6 \pm 0.08 * * *$ & $60 \%$ \\
\hline $\begin{array}{l}\text { Mice treated with } \\
\text { tamoxifen \& } \\
\text { vitamin C }\end{array}$ & $30.7 \pm 0.04$ & $-2.85 \%$ & $22.1+0.86^{*}$ & $-1.38 \%$ & $6.2 \pm 0.38$ & $6.9 \%$ & $3.7 \pm 0.12$ & $5.71 \%$ \\
\hline
\end{tabular}

$* p<0.05, * * p<0.01 \& * * * p<0.001$

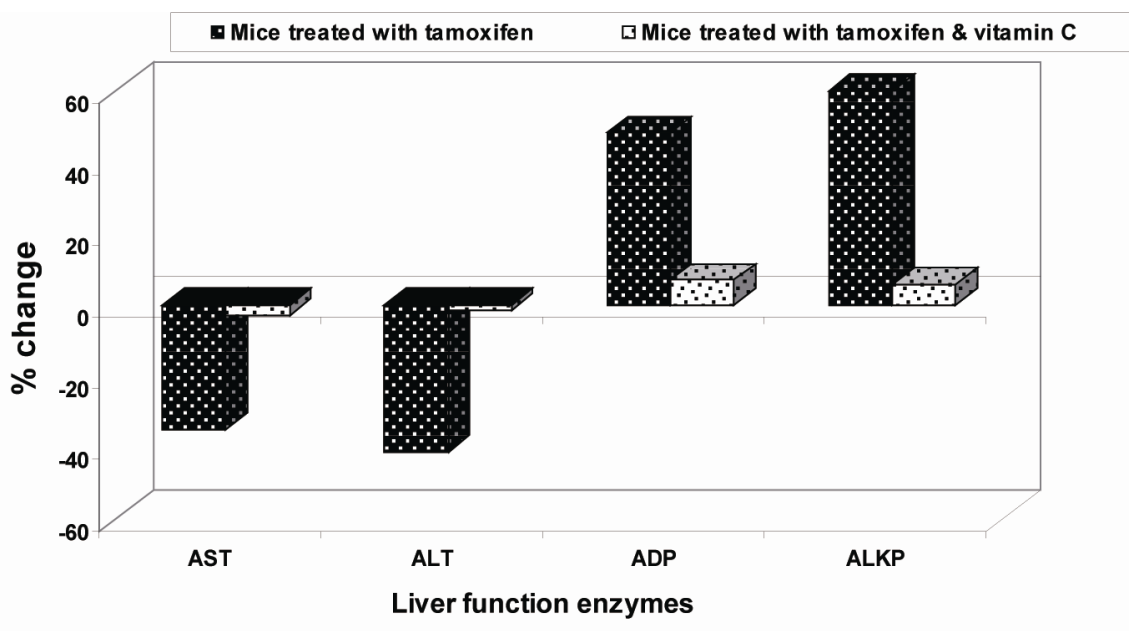

Figure 3. Percentage change in the activity of liver function enzymes of mice treated with Tamoxifen and Tamoxifen with vitamin $\mathrm{C}$. 
Table 4. Effect of tamoxifen and vitamin $\mathrm{C}$ on biochemical parameters in mice.

\begin{tabular}{|c|c|c|c|c|c|}
\hline \multirow{2}{*}{$\begin{array}{l}\text { Treatment } \\
\text { parameters }\end{array}$} & \multirow{2}{*}{$\begin{array}{c}\text { Control } \\
\text { Mean } \pm \text { SD }\end{array}$} & \multicolumn{2}{|c|}{ Mice treated with tamoxifen } & \multicolumn{2}{|c|}{ Mice treated with tamoxifen \& vitamin $C$} \\
\hline & & Mean \pm SD & $\%$ Change & Mean \pm SD & $\%$ change \\
\hline Total protein & $31.6 \pm 3.1$ & $21.8 \pm 2.11^{* *}$ & $-31.01 \%$ & $30.5 \pm 3.1$ & -3.48 \\
\hline Glycogen & $20.5 \pm 1.03$ & $12.8 \pm 0.75 * * *$ & $-37.56 \%$ & $19.5 \pm 3.31$ & $-5.85 \%$ \\
\hline Glucose & $30.7 \pm 0.04$ & $22.1+0.86^{* *}$ & $-28.1 \%$ & $-29.8 \pm 2.38$ & $-2.93 \%$ \\
\hline Total Cholesterol & $2.1 \pm 1.2$ & $1.6 \pm 0.13 * *$ & $-25.71 \%$ & $1.98 \pm 0.06$ & $-5.71 \%$ \\
\hline Uric Acid & $52.13 \pm 0.4$ & $34.3 \pm 4.1 * *$ & $-34.2 \%$ & $50.8 \pm 4.3$ & $-2.55 \%$ \\
\hline Urea & $6.2 \pm 0.4$ & $4.5 \pm 1.1 * *$ & $-27.42 \%$ & $6.1 \pm 0.73$ & $-1.62 \%$ \\
\hline Creatinine & $35.1 \pm 2.1$ & $28.4 \pm 3.6^{*}$ & -19.32 & $34.6 \pm 1.8$ & $-1.42 \%$ \\
\hline
\end{tabular}

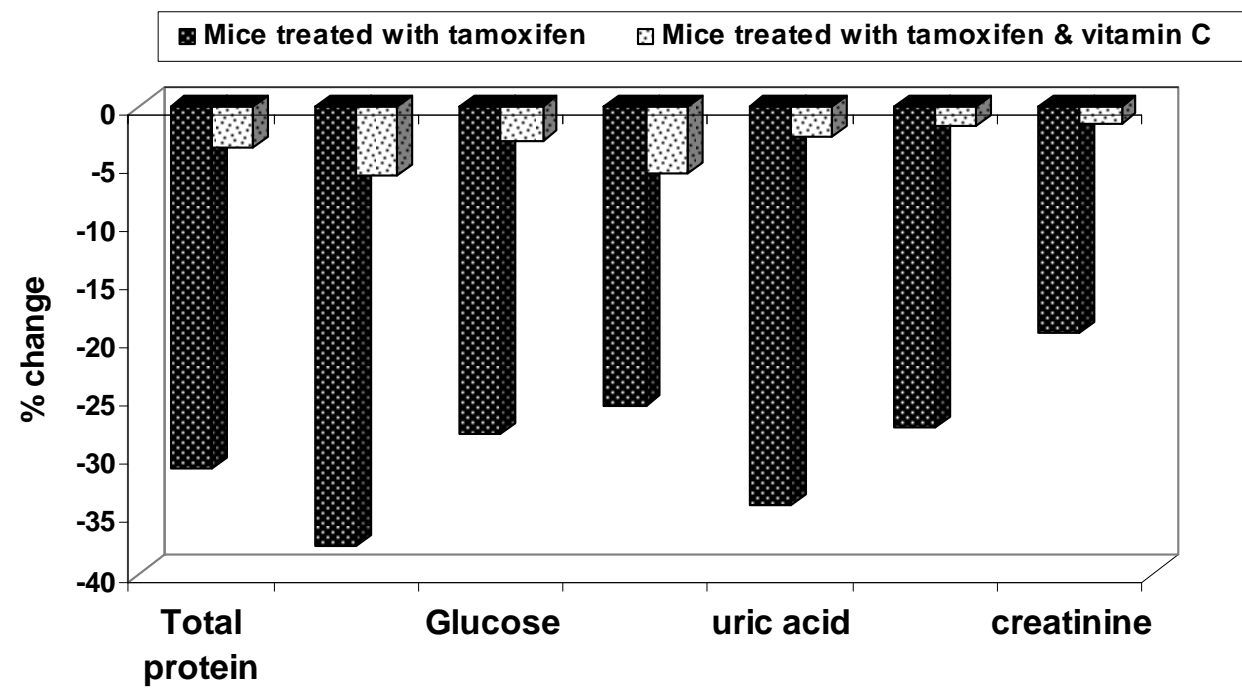

Figure 4. Percentage change in biochemical paramters of mice treated with Tamoxifen and Tamoxifen with vitamin $\mathrm{C}$.

Pase as glycogenolytic enzyme, it showed an enhanced activity in treated mice which was attributed to either synthesis and/or degradation of glycogen [34], inhibition of translocase (T1) the glucose-6-phosphate transport protein [35] and to the elevation of cytosolic calcium that can trigger the conversion of the enzyme phosphorylase $\mathrm{b}$ (inactive form) to phosphorylase a (active form) which degrades glycogen into glucose [36].

Concerning AST and ALT enzymes activities, significant reduction was observed in both treated mice. The present result indicated that decrease in AST and ALT attributed to the hepatocellular damage where the transaminases level showed an intimate relationship to cell necrosis and/or increased cell membrane permeability led to discharge of the enzyme to blood stream $[37,38]$. The decrease in transaminases level providing additional support for the side effect of the toxic substance on mitochondria of the hepatic cells as it is the subcellular localization of transaminases.

In the present study, acid phosphatase (ACP) and alkaline phosphatase (ALP) showed that significant elevation in treated mice. Higher levels of acid phosphatase and alkaline phosphatase (ALP) in tissue was observed by El-Aasar et al. [37] and Abdel-Rahman et al. [39] which was attributed to the irritation of liver cells by toxins or due to increase loss of intracellular enzyme by diffusion through cell membrane which appear to act as a stimulus to the synthesis of more enzyme.

Tamoxifen was reported to alter the glutathione metabolizing enzymes [40]. Tamoxifen induces free radicals production in renal tissue, and at the same time decreases its ability to detoxify reactive oxygen species. TM intoxication leads to disruption of the activity of glutathione metabolizing and antioxidant enzymes [5].

There is no side effects on all glycolytic, gluconeogenic and glycogenolytic and liver function enzymes of 
mice treated with tamoxifen with vitamin $\mathrm{C}$ as compared to the normal healthy control group. The results of the present study indicated that the exogenously administered vitamin $\mathrm{C}$ may prevent tamoxifen-induced testes toxicity in mice. The protective effect of vitamin $\mathrm{C}$ is probably due to a counter action of free radicals by its antioxidant nature. Vitamin $\mathrm{C}$ may be recommended as an adjuvant therapy with certain anticancer. Protective effects of vitamin $\mathrm{C}$ against chemically-induced damage in various rodent organs have been demonstrated by many investigators [41,42]. Vitamin $\mathrm{C}$ was found to be effectively protecting chemically-induced oxidative renal damage in animals [42-44] reported that mega-dose of vitamins rendered significant protection of renal damage induced by anticancer and the effect of vitamin $\mathrm{C}$ was higher than that of vitamin $\mathrm{E}$. The protective effects may be partially mediated by preventing the renal antioxidant status.

Increasing the glucose concentration stimulated glycogen synthesis and decreased the activity of glycogen phosphorylase. An inverse relationship was shown between the actual glycogen content and the rate of glycogenesis. So there is a substrate cycling that occurred between glucoses-6- phosphate and glycogen content, i.e. glucose was incorporated into glycogen during period of net glycogen breakdown, and vice versa; glycogen degradation occurred during periods of net glycogen synthesis which depends on glucose concentration [27]. Our data recorded enhancement levels of glucose-6-phosphatase and glucose.

The present results showed that significant reduction in total protein content in treated mice which could be attributed to cellular damage caused by toxins [30]. The main fraction of total protein content is albumin in turn may result from decrease anabolism or increase catabolism [45]. The significant decrease in total protein is mainly due to increase in messenger RNA degradation which is the possible cause for the hypoalbuminemia [46]. Also, the present results showed that very highly significant reduction in total cholesterol, uric acid, urea and creatinine in mice treated with tamoxifen as compared to the normal healthy control.

\section{CONCLUSIONS}

Normal control mice treated with tamoxifen showed side effects of most parameters compared to the normal healthy control group. Moreover, normal control mice treated with tamoxifen and vitamin $\mathrm{C}$ showed no side effects of most parameters compared to the normal healthy control group. Hence, vitamin $\mathrm{C}$ may prevent tamoxifen-induced testes toxicity in mice.

\section{REFERENCES}

[1] Phillips, D.H. (2001) Underatanding the genotoxicity of tamoxiifen. Carcinogenesis, 22, 839-849. doi:10.1093/carcin/22.6.839

[2] Rang, H.P., Dale, M.M. and Ritter, J.M. (1995) The Reproductive system Pharmacology. Fourth edn. Churchill Livingstone, Edinburgh, London, New York, Philadelphia, Sydney and Toronto.

[3] Pirkko, H., Annukka, A. and Eero, M. (2002). Toxicity of antiestrogen. The Breast Journal (U.S.A), 8, 92-96.

[4] Gamboa-da-costa, G., Marques, M.M., Beland, F.A., Freeman, J.P., Churchwell, M.L. and Doerge, D.R. (2003) Quantification of Tamoxifen DNA adducts using on lines sample preparation and HPLC-electrospray ionization tandem mass spectrometry. Chemical Research in Toxicology, 16, 357-366. doi:10.1021/tx020090g

[5] Albert, P.L., Bode, C. and Sakai, Y. (2004). A novel in vitro system, the integrated discrete multiple organ cell culture (I dMOC)) system, for the evaluation of human toxicity: Comparative cytotoxicity tamoxifen towards normal human cells from five major organs and MCF-7 andenocarcinoma breast cancer. Chemico-Biological Interactions, 150, 129-136. doi:10.1016/j.cbi.2004.09.010

[6] Kadkhodaee, M., Khastar, H., Faghih, M., Ghaznavi, R. and Zahmarkesh, M.,2005. Effect of co-suplementation and of vitamin $\mathrm{E}$ and $\mathrm{C}$ on gentamicin-induced nephrotoxicity in rat. Experimental Physiology, 90, 571-576. doi:10.1113/expphysiol.2004.029728

[7] Abd El-Monem, S.; Bakry, F.A. and Ismail, S.M. (2006) Influence of and niclosimide on some biological and physiological parameters of lymnaea natalensis snails as intermediate host of fasciola gigantica. Egyptian Journal of Zoology, 46, 227-244.

[8] Sakran A.M.A and Bakry F.A (2005) Biological and physiological studies on Biomphalaria alexandrina snails exposed to different plant molluscicides. Journal of Egypt German Society of Zoology, 48A, 237-256.

[9] Paget, G. and Barners, J. (1964) Toxicity tests. In: Laurence, D.R. and Bacharach, A.L. Eds., Evalution of Drug Activities: Pharmacometrics, Academic Press, London and New York, 135-166.

[10] Uyeda, K. and Racker, E. (1965): Regulatory mechanisms in carbohydrate metabolism. VII. Hexokinase and phosphofructokinase. The Journal of Biological Chemistry, 240, 4682-4688.

[11] McManus, D.P. and James, B.L. (1975) Anaerobic glucose metabolism in the digestive gland of Littorina saxatilis rudis (Maton) and the daughter sporocysts Microphallus Similis (jag). Comparative Biochemistry and Physiology, 51, 293-297.

[12] King, J. (1965) Glucose phosphate isomerase. In: Practical Clinical Enzymology. Van Nostr and Co. Ltd., London, 1113-1117.

[13] Zammit, V.A., Beis, I. and Newsholme, E.A. (1978) Maximum activities and effects of fructose bisphosphate on pyruvate kinase from muscles of vertebrates and invertebrates in relation to the control of glycolysis. Biochemical Journal, 174, 989-998.

[14] Cabaud, P. and Wroblewski, F. (1958) Colorimetric measurement of lactic acid dehydrogenase activity of body fluids. American Journal of Clinical Pathology, 30, 234236.

[15] Suarez, R.K., Mallet, M.D., Doxboeck, C. and Hochacjka, P.W. (1986) Enzymes of energy metabolism and glu- 
coneogenesis in acid blue malin, Makaira nigricans. Canadian Journal of Zoology, 64, 694-697. doi:10.1139/z86-102

[16] Swanson, M.A. (1955) Glucose-6-phosphatase from liver. Methods in Enzymology, 2, 541-543. doi:10.1016/S0076-6879(55)02247-7

[17] Sand, O., Petersen, L.M. and Emmersen, B.K. (1980) Changes in some carbohydrate metabolizing enzymes and glycogen in liver, glucose and lipid in serum during vitellogenesis and after induction by estradiol-1-7-B in the flounder Platichtys flesus L. Comparative Biochemistry and Physiology, 65, 327-332. doi:10.1016/0305-0491(80)90021-8

[18] Hedrick, J.L. and Fischer, E.H. (1965) On the role of pyridoxal-5-phosphate in phosphorylase, absence of classical vitamin B6 dependent enzymatic activities inmuscle glycogen phoshorylase. Biochemistry, 4, 13371344.

[19] Reitman, S. and Frankel, S. (1957) A colorimetric method for the determination of serum glutamic oxaloacetic and glutamic pyruvic transaminases. American Journal of Clinical Pathology, 28, 56-63.

[20] Fishman, W.H. and Ferner, F. (1953) A method for estimating serum acid phosphatase of prostatic origin. The Journal of Biological Chemistry, 200, 89-97.

[21] King, P.R. and King, E.J. (1954) Estimation of plasma phosphatase by determination of hydrolysed phenol (with amino-antipyrine). Journal of Clinical Pathology, 7, 322-326. doi:10.1136/icp.7.4.322

[22] Lowery, O.H., Rose Brough, N.J., Farr, A.L. and Randall, R.J. (1951) Protien measurement with the folin-phenol reagent. The Journal of Biological Chemistry, 2, 265-275

[23] Nicholas, V., Carroll, R., Longley, W. and Joseph, H.R. (1956) The determination of glycogen in liver and muscle by the use of anthrone reagent. The Journal of Biological Chemistry, 220, 583-593.

[24] Trinder, P. (1969): Determination of glucose in blood using glucose oxidase with an alternative oxygen acceptor. Annals of Clinical Biochemistry, 6, 24-27.

[25] Spiegel, R.M. (1981) Theory and problems of Statistics, Schaum's outline series. McGraw-Hill, Singapore.

[26] Ahmed, S.A. and Gad, M.Z. (1995) Effect of schistosomal infection and its treatment on some key enzymes of glucose metabolism in mice livers Arznein. Forsch, 45, 1324-1330.

[27] Tielens, A.G. (1997) Biochemistry of Trematode. In Fried, B. and Graczyk, T.K. Eds., Advances in Trematode Biology, CRC Press, Boca Raton, 309-343.

[28] Kuser, P.R. Krauchrenco, S., Antunes, O.A. and Polikarpov, I. (2000) The high resolution crystal structure of yeast hexokinase PII with the correct primary sequence provides new insights into its mechanism of action. The Journal of Biological Chemistry, 275, 20814-20821.

[29] Paul, J., Bekker, A.Y. and Duran, W.N. (1990) Calcium entry prevents leakage of macromolecules induced by ischemia-reperfusion in skeletal muscle. Circulation Research, 66, 1636-1642.

[30] Parasad, M.R., Popeseu, L.M., Moraru, I.I, Liu, X., Maity, S., Engelman, R.M. and Das, D.K. (1991) Role of phospholipase $\mathrm{A}$ and $\mathrm{C}$ in myocardial ischemic reperfusion injury. American Journal of Physiology, 29, H877-H883.

[31] Reddy, A.N., Venugopal, N.B.R.K. and Reddy, S.L.N.
(1995) Effect of endosulphan 35 EC on some biochemical changes in the tissues and haemolymph of a fresh water field crab, Barytelphusa guerini. Bulletin of Environmental Contamination and Toxicology, 55, 116-121. doi:10.1007/BF00212397

[32] El-Ansary, A., El-Bardicy, S., Soliman, S.M. and Zayed, N. (2000) Sublethal concentration of Ambrosia maritima (Damsissa) affecting compatibility of Biomphalaria alexandrina snails to infection with Schistosoma mansoni through disturbing the glycolytic pathway. Journal of the Egyptian Society of Parasitology, 30, 809-819.

[33] Horemans, A.M.C., Tielens, A.G.M. and Van Den Bergh, S.G. (1992) The reversible effect of glucose on the energy metabolism of Schistosoma mansoni cercariae and schistosomual. Molecular and Biochemical Parasitology, 51, 73-79. doi:10.1016/0166-6851(92)90202-U

[34] Mchael, A.L., Wahab, R.A., Guriguis, N.M., El-Gazayerli, L.M. and Hamza, S. (1979) Effect of Schistosoma mansoni infection in mice on hydrolytic enzyme activity of the liver. Journal of the Egyptian Society of Parasitology, 6, 37-44.

[35] Scott, H.M., Coughtrie, M.W. andBurchell, A. (1991) Steroid sulfates inhibit rat hepatic microsomal glucose-6phosphatasesystem. Biochemical Pharmacology, 41, 1529-1532. doi:10.1016/0006-2952(91)90572-M

[36] Exton, J.H. (1982) Regulation of carbohydrate Metabolism by Cyclic Nucleotides. In: Kehalian, J.W. and Nathasan, J.A. Eds., Cyclic Nucleotides. II. Handbook of Experimental Pharmacology, 58, Springer-Verlag, Berlin, 3-88.

[37] El-Aasar, A.A., El-Merzabani, M.M, Zakhary, N.I., Farag, H.I, Abdeen, A.M, Abd El-Salam, I. and Mokhtar, N.M. (1989) Biochemical and biophysical studies on schistosomal liver of mice. Egypt. J. Bilh., 11, 19-33.

[38] El-Shazly, A.M., Soliman, M., El-Kalla, M.R., Rezk, H., El-Nemr, H.E., Handousa, A.E. and Helmy, M.M. (2001) Studies on patients with Schistosoma mansoni; HCV and/or typhoid fever. Journal of the Egyptian Society of Parasitology, 31, 583-592.

[39] Abdel-Rahman, H.M., El-Shanawani, F.M., Hassan, M.M., Salem, M. and El-Salhy, A.M. (1993) Alkaline phosphatase isoenzymes abnormalities in hepatic schistosomiasis. Egypt iournal of Bilharzia, 15, 41-48.

[40] El-Beshbishy, H. (2005) Hepatoprotective effect of green tea (Camellia sinensis) extract against tamoxifen-induced liver injury in rats. Journal of Biochemistry and Molecular Biology, 38, 563-570. doi:10.5483/BMBRep.2005.38.5.563

[41] Zaidi, S.M. and Banu, N. (2004) Antioxidant potential vitamin $\mathrm{A}, \mathrm{E}$ and $\mathrm{C}$ in modulating oxidative stress in rat brain. Clinica Chimica Acta, 33, 229-340 doi:10.1016/j.ccen.2003.11.003

[42] Ajith, T.A., Usha, S. and Nivitha, V. (2007) Ascorbic acid and $\alpha$-Tocopherol protect renal damage. Clinical and Experimental Nephrology, 9, 24-30

[43] Naziroglu, M., Kuraoglu, A. and Aksoy,A. 2004. Selenium and high dose vitamin $\mathrm{E}$ administration protects cisplatin-induced oxidative damage to renal and lens tissue in rat. Toxicology, 195, 221-230 doi:10.1016/i.tox.2003.10.012

[44] Abraham, P. (2005) Vitamin C may be beneficial in the prevention of paracetamol-induced renal damage. Clini- 
cal and Experimental Nephrology, 9, 24-30. doi:10.1007/s10157-004-0335-6

[45] El-Fakahany, A.F.M., Abdalla, K.F., El-Hady, H.M., El-Aziz, S.M.A. and Afifi, L.M. (1993) The effect of Praziquantel treatment on the liver function, worm burden, and granuloma size using two drug regimens in marine
Schistosoma mansoni infection. Journal of the Egyptian Society of Parasitology, 23, 877-882.

[46] Metwally, A.A., Jaku, I., Komper, F., Khayyal, M.T., Fbeid, F.A. and Botros, S.S. (1990) Effect of schistosomiasis infection on the clearance of phenazone in mice. Arzneimittel Forschung, 40, 206-209. 